\title{
REVIEW
}

Open Access

\section{Methods for accounting for neighbourhood self-selection in physical activity and dietary behaviour research: a systematic review}

Karen E. Lamb ${ }^{1,2,3^{*}}$ D, Lukar E. Thornton ${ }^{1}$, Tania L. King ${ }^{4}$, Kylie Ball ${ }^{1}$, Simon R. White ${ }^{5}$, Rebecca Bentley ${ }^{4}$, Neil T. Coffee ${ }^{6}$ and Mark Daniel $\left.\right|^{6,7}$

\begin{abstract}
Background: Self-selection into residential neighbourhoods is a widely acknowledged, but under-studied problem in research investigating neighbourhood influences on physical activity and diet. Failure to handle neighbourhood self-selection can lead to biased estimates of the association between the neighbourhood environment and behaviour. This means that effects could be over- or under-estimated, both of which have implications for public health policies related to neighbourhood (re)design. Therefore, it is important that methods to deal with neighbourhood self-selection are identified and reviewed. The aim of this review was to assess how neighbourhood self-selection is conceived and accounted for in the literature.

Methods: Articles from a systematic search undertaken in 2017 were included if they examined associations between neighbourhood environment exposures and adult physical activity or dietary behaviour. Exposures could include any objective measurement of the built (e.g., supermarkets), natural (e.g., parks) or social (e.g., crime) environment. Articles had to explicitly state that a given method was used to account for neighbourhood selfselection. The systematic review was registered with the PROSPERO International Prospective Register of Systematic Reviews (number CRD42018083593) and was conducted in accordance with the Preferred Reporting Items for Systematic Reviews and Meta-Analyses (PRISMA) statement.

Results: Of 31 eligible articles, almost all considered physical activity (30/31); few examined diet (2/31). Methods used to address neighbourhood self-selection varied. Most studies (23/31) accounted for items relating to participants' neighbourhood preferences or reasons for moving to the neighbourhood using multi-variable adjustment in regression models (20/23) or propensity scores (3/23). Of 11 longitudinal studies, three controlled for neighbourhood self-selection as an unmeasured confounder using fixed effects regression.

(Continued on next page)
\end{abstract}

\footnotetext{
* Correspondence: karen.lamb1@deakin.edu.au

'School of Exercise and Nutrition Sciences, Institute for Physical Activity and Nutrition (IPAN), Deakin University, Geelong, Australia

${ }^{2}$ Clinical Epidemiology and Biostatistics Unit, Murdoch Children's Research Institute, Melbourne, Australia

Full list of author information is available at the end of the article
} 
(Continued from previous page)

Conclusions: Most studies accounted for neighbourhood self-selection by adjusting for measured attributes of neighbourhood preference. However, commonly the impact of adjustment could not be assessed. Future studies using adjustment should provide estimates of associations with and without adjustment for self-selection; consider temporality in the measurement of self-selection variables relative to the timing of the environmental exposure and outcome behaviours; and consider the theoretical plausibility of presumed pathways in cross-sectional research where causal direction is impossible to establish.

Keywords: Bias, Neighbourhood characteristics, Exercise, Diet, Environmental exposure, Adult

\section{Background}

Conceptual models suggest that the neighbourhoods in which we live have the potential to affect health-related behaviours such as physical activity and dietary behaviours [1-4]. A growing body of research has investigated links between the local built, natural and social environment on modifiable health-related behaviours [5-7]. While some consistent links have been found (e.g., neighbourhood walkability is associated with active transport [8]), much research on neighbourhood effects on physical activity and dietary behaviours has shown mixed findings $[9,10]$.

Two challenges in identifying whether environmental features have a causal effect on physical activity and dietary behaviours are that most studies have relied on observational and cross-sectional data. It is rarely ethical or feasible to randomly allocate individuals to live in one neighbourhood or another; the Moving to Opportunity Study in the US being an uncommon example of such an intervention [11]. The preclusion of randomisation is a key obstacle in determining whether observed associations are due to differences in the local environment or other, unmeasured, factors. So, too, does the lack of temporal ordering (possible with longitudinal but not cross-sectional studies) pose challenges for causal inference. A reliance on non-randomised, cross-sectional studies poses serious problems in ruling out a potential impact of neighbourhood self-selection on exposure to particular environment features and health-related behaviours presumed related to these.

Neighbourhood self-selection (also referred to as residential self-selection), refers to people selecting neighbourhoods to live in that have the facilities and resources that suit their preferred lifestyle. If neighbourhood self-selection bias exists, it can be difficult to differentiate the effect of neighbourhood features on behavioural outcomes from the choice to be near features facilitating these preferred behaviours. Consider, for example, the issue of identifying the effect of living near some neighbourhood environment feature, such as parks or sports facilities, on a health-related behavioural outcome, such as physical activity. It could be that individual preference for spending time walking or exercising in parks drives the individual's selection into a neighbourhood with parks (i.e., the individual "self-selects" into a neighbourhood that supports their preference for walking or exercising in parks). However, this preference also predicts the individual's health-related behaviour (i.e., their physical activity in this example), as shown in Fig. 1. Therefore, failure to account for this neighbourhood selfselection may bias the estimated effect of the neighbourhood environment feature on the behavioural outcome. This means that the effect could be over- or underestimated which has implications for public health policies related to neighbourhood (re)design. Neighbourhood selfselection can also occur if people are restricted in their choice of neighbourhood due to the affordability of housing. As discussed by Boone-Heinonen, GordonLarsen [12], if lower socioeconomic status neighbourhoods have limited or poor physical activity facilities and residents undertake less physical activity then the relationship between the neighbourhood environment and physical activity could be overestimated. Whilst increasingly acknowledged, neighbourhood self-selection remains an under-studied phenomenon.

Methods for dealing with neighbourhood self-selection have been discussed in physical activity research [12, 13]. In their narrative review, Boone-Heinonen et al. [12] highlighted how longitudinal designs are preferable to enable neighbourhood self-selection to be taken into account in observational research. These designs allow for temporal ordering of exposure and outcome, as well as the possibility of examining within-individual change. In a systematic review of built environment and physical activity associations, McCormack and Shiell [13] identified a range of methods for accounting for neighbourhood self-selection, such as confounder adjustment (including the use of propensity scores) and instrumental variables. The authors noted, however, that while few cross-sectional studies adjust for neighbourhood selfselection, those studies contribute in great number to the current evidence base. However, this systematic review focussed primarily on the research findings themselves, rather than a discussion and critique of the methods for accounting for neighbourhood self-selection. To our knowledge, there have been no systematic reviews focussed on 


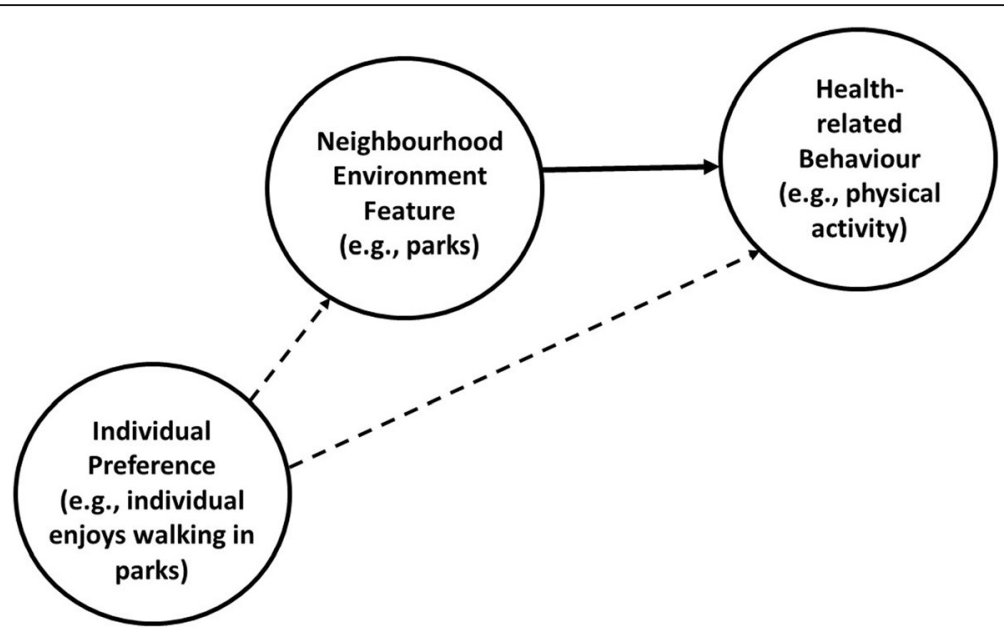

Fig. 1 Directed acyclic graph of neighbourhood self-selection as a confounder of the association between a neighbourhood environment feature and a health-related behavioural outcome

examining methods to account for neighbourhood selfselection in neighbourhood environment and physical activity research. Furthermore, there have been no reviews examining methods to deal with neighbourhood selfselection in neighbourhood environment and dietary behaviour research.

Given the potential for neighbourhood self-selection to influence estimated associations between the neighbourhood environment and both physical activity and dietary behaviours, our aims were to identify, and critique, methods used to account for and reduce the impact of self-selection on estimated associations. Specifically, our research questions were: 1) How is neighbourhood selfselection conceived in the literature on research in relation to physical activity and dietary behaviour?; 2) What methods are used to assess its impact?; and 3) amongst studies adjusting for neighbourhood self-selection (e.g., using regression based confounder adjustment), to what extent are results presented both with and without adjustment, and if so, what is the scope of variation in the study findings? Results were used to inform recommendations regarding suitable approaches for future research on neighbourhood influences on physical activity and dietary behaviour.

\section{Methods}

\section{Search strategy}

Search terms for neighbourhood self-selection were based on terms used in articles identified in an initial scoping review in PubMed conducted by KEL in March 2017. Search terms for physical activity were informed by those used elsewhere when examining associations between the built environment and physical activity [13]. The terms "strolling", "leisure-time", "recreation", "inactivity" and "pedestrian" were excluded from the physical activity search terms to focus the search on physical activity more broadly. Search terms for diet were informed by those used elsewhere to examine associations between the food environment and diet [10]. The initial list of search terms proposed for physical activity and diet is presented in Supplementary Table 1.

Searches of these initial terms were conducted separately for each list (i.e., neighbourhood terms, self-selection terms, physical activity terms, and diet terms), as well as in combination using 'or' between items within each list, and 'and' between the different lists. Searches were conducted in Scopus, PubMed, Academic Search Complete, Education Source, ERIC, Global Health, MEDLINE Complete, SPORTDiscus, and PsycInfo through EBSCOHost on 6th July 2017 by KEL and LET. This enabled assessment of the number of articles identified using these search terms to aid in determining which terms should be included in the final search. The preliminary searches were conducted using a step by step process, first assessing the neighbourhood search terms and then adding the self-selection terms. As over 280,000 articles were identified combining the neighbourhood and self-selection terms, the search terms were reviewed to ensure relevance. This resulted in a decision to group the two neighbourhood and self-selection search terms, shown in Supplementary Table 1, together as a single neighbourhood self-selection term (e.g., "neighbo\#rhood selfselect" $\left.{ }^{* \prime \prime}\right)$. The final list of search terms considered in this review by database is presented in Table 1. Identified articles were transferred into EndNote. In total, 3953 articles were identified in the search, which was conducted on 19th July 2017, with 287 identified as duplicates leaving 3666 articles for screening. 
Table 1 Search conducted for the systematic review of methods to account for self-selection in neighbourhoods and physical activity and diet research

\begin{tabular}{|c|c|c|c|}
\hline Database & Search terms & Restrictions & $\begin{array}{l}\text { Number of } \\
\text { articles }\end{array}$ \\
\hline $\begin{array}{l}\text { EBSCOHost } \\
\text { (Academic Search Complete, } \\
\text { Education Source, ERIC, } \\
\text { Global Health, MEDLINE } \\
\text { Complete, SPORTDiscus, } \\
\text { Psyclnfo) }\end{array}$ & $\begin{array}{l}\text { ("neighbo\#rhood self-select*" OR "neighbo\#rhood self } \\
\text { select*" OR "neighbo\#rhood select*" OR "residential } \\
\text { self-select*" OR "residential self select*" OR "residential } \\
\text { decisions" OR "self-selection bias" OR "self selection bias" } \\
\text { OR "residential location decision" OR "neighbo\#rhood } \\
\text { choice" OR "neighbo\#rhood preference" OR "residential } \\
\text { mobility") } \\
\text { AND } \\
\text { ("physical activit*" OR exercis* OR walk* OR cycl* OR } \\
\text { bicycle* OR sport* OR "active transport*" OR "active } \\
\text { travel" OR diet* OR nutrition* OR consumption OR food) }\end{array}$ & $\begin{array}{l}\text { Adult } \\
\text { (19+ years) } \\
\text { English } \\
\text { language } \\
\text { Academic } \\
\text { journals }\end{array}$ & 1241 \\
\hline PubMed & $\begin{array}{l}\text { ("neighborhood self-select*" OR "neighbourhood } \\
\text { self-select" }{ }^{*} \text { OR "neighborhood self select*" OR " } \\
\text { neighbourhood self select*" OR "neighborhood select*" } \\
\text { OR "neighbourhood select*" OR "residential self-select*" } \\
\text { OR "residential self select*" OR "residential decisions" OR } \\
\text { "self-selection bias" OR "self selection bias" OR "residential } \\
\text { location decision" OR "neighborhood choice" OR } \\
\text { "neighbourhood choice" OR "neighborhood preference" } \\
\text { OR "neighbourhood preference" OR "residential mobility") } \\
\text { AND } \\
\text { ("physical activit*" OR exercis* OR walk* OR cycl* OR } \\
\text { bicycl* OR sport* OR "active transport*" OR "active travel" } \\
\text { OR diet* OR nutrition* OR consumption OR food) }\end{array}$ & $\begin{array}{l}\text { Adult } \\
\text { (19+ years) } \\
\text { English } \\
\text { language } \\
\text { Humans }\end{array}$ & 1387 \\
\hline Scopus & $\begin{array}{l}\text { ("neighborhood self-select*" OR "neighbourhood } \\
\text { self-select*" OR "neighborhood self select*" OR } \\
\text { "neighbourhood self select*" OR "neighborhood select*" } \\
\text { OR "neighbourhood select*" OR "residential self-select*" } \\
\text { OR "residential self select*" OR "residential decisions" OR } \\
\text { "self-selection bias" OR "self selection bias" OR "residential } \\
\text { location decision" OR "neighborhood choice" OR } \\
\text { "neighbourhood choice" OR "neighborhood preference" } \\
\text { OR "neighbourhood preference" OR "residential mobility") } \\
\text { AND } \\
\text { ("physical activit*" OR exercis* OR walk* OR cycl* OR } \\
\text { bicycl* OR sport* OR "active transport*" OR "active travel" } \\
\text { OR diet* OR nutrition* OR consumption OR food) }\end{array}$ & $\begin{array}{l}\text { Adult } \\
\text { English } \\
\text { language } \\
\text { Journal } \\
\text { article } \\
\text { Human }\end{array}$ & 1325 \\
\hline
\end{tabular}

\section{Screening}

Two assessors independently conducted the title and abstract screening using the Rayyan app [14]. As methods for dealing with self-selection may not appear in the title or abstract, the assessors did not consider self-selection in the initial screening. To be included, articles had to: 1) be original research articles (i.e., not commentary or review articles); 2) be published as articles in refereed journals; 3) be published in English; 4) feature adult participants (i.e., $\geq 18$ years of age); 5 ) include a physical activity or dietary behaviour (including food purchasing behaviours) outcome; 6) include an objectively-assessed measure of the built (e.g., food outlets, sport or recreational centres), natural (e.g., parks) or social (e.g., neighbourhood disadvantage, crime) environment as an exposure variable (articles that dealt with perceived rather than objectively assessed neighbourhood environment measures were excluded; neighbourhood environment exposure could include exposures defined for administrative units (e.g., postcode), as well as measures defined around the home address, such as buffer or proximity measures); and 7) include only community-dwelling participants (participants in hospital settings or residential care settings were excluded). Where there were disagreements, a third assessor examined the title and abstracts according to the inclusion criteria. Those that met the inclusion criteria (or, where it was not clear from the abstract that the inclusion criteria had been met) were considered in the full text assessment. Two assessors independently assessed the full text of the articles according to the same criteria applied for the title and abstract screening. A third assessment, conducted independently by two additional assessors, considered all articles that met these inclusion criteria, in addition to any where it was unclear that the criteria had been met, to determine whether self-selection had been considered.

\section{Data extraction}

A data extraction template was created in Excel. The following information was collated from the articles 
included in this review: author information, article title, study setting, study design (e.g., cross-sectional, longitudinal), characteristics of participants sampled (e.g., age, gender), neighbourhood environment exposure, physical activity or diet outcome details, confounder adjustment in analyses, in addition to the method used to address neighbourhood self-selection and any limitations stated about this approach.

\section{Review registration}

This review was registered with the PROSPERO International Prospective Register of Systematic Reviews (number CRD42018083593) and was conducted in accordance with the Preferred Reporting Items for Systematic Reviews and Meta-Analyses (PRISMA) statement.

\section{Results}

Of 3666 articles identified, 31 were included in the review (see Fig. 2).

A summary of included articles is presented in Table 2 . Most articles reported on data from the USA (13/31) or Australia (8/31). Twenty articles featured cross-sectional analysis, 10 longitudinal analysis and one both crosssectional and longitudinal (Table 2). Data from some studies featured in more than one article. For example, data from the Residential Environments Project (RESIDE) featured in five of the articles [22, 23, 26, 31, 34].

\section{Outcomes}

A majority of studies (30/31) considered a physical activity outcome or outcomes, with walking the most commonly considered (23/30). Only two studies considered a dietary behaviour outcome $[15,17]$, with one of these also considering physical activity outcomes [15].

\section{Exposures}

Nineteen articles considered individual-level environment exposure variables (e.g., total area of park space within $1 \mathrm{~km}$ of each participant's home address [30]), 11 considered area-level exposure variables (e.g., percentage of green space within the census areal units in which participants reside [37]) and one article considered an area-level exposure variable but treated it as an individual-level exposure variable in the analysis as there were few individuals within each neighbourhood [18] (Table 2). Seventeen studies considered only built environment exposures (e.g., retail outlets [28]; residential density [16]; food outlets [17, 21, 28]). Two considered only natural environment exposures (parks [30]; green space [37]), while three considered only social environment exposures (socioeconomic disadvantage [15, 18]; crime [23]). Nine studies considered mixed exposure types. Fourteen studies considered a single exposure variable $[15,18,19,23,24,29,30,35-39,42,44]$, although one was derived from a cluster analysis of mixed environment exposure variables [35]. Walkability was the most commonly considered of these single exposure variables $[19,25,29,35,36,38,39,42]$.

\section{Approaches for dealing with neighbourhood self-selection Model adjustment}

Twenty articles used model adjustment to deal with measured neighbourhood self-selection variables (Table 3).

One article, after stratifying by gender, adjusted only for age, education and marital status; these variables being framed as important confounding factors influencing neighbourhood choice [15]. These variables were typically adjusted for in the other articles included in this review, although they generally were not referred to as measures of neighbourhood self-selection. Instead, other measures relating to reasons for moving to or living in a neighbourhood were referred to as measures of neighbourhood self-selection, as described below.

Most articles that used model adjustment attempted to capture neighbourhood self-selection by measuring the importance of characteristics (such as local access to schools or recreational facilities) for living or moving to a participant's current neighbourhood or home $(11 / 20)$ [22, 23, 25, 26, 29, 30, 34, 39-42], or when looking to move (1/20) [28]. Others considered neighbourhood preference items $(2 / 20)[37,45]$, such as preference to live in an urban or suburban environment [45], or both the importance of characteristics and preference $(2 / 20)$ [24, 38]. Two studies that reported using model adjustment provided little detail on the neighbourhood selfselection variables $[27,32]$.

\section{Propensity scores}

Three articles used propensity scores to deal with measured neighbourhood self-selection variables $[33,35,36]$ (Table 3). McCormack et al. (2012) estimated the conditional probabilities of participants living in each of three neighbourhood clusters based on neighbourhood selfselection, in addition to the length of residence in current neighbourhood, attitude towards walking, sociodemographic characteristics, and the season the survey was conducted [35]. Nineteen self-selection items were included. A similar approach was used by McCormack et al. (2017) to examine associations between walkability ("maintainers", "improvers", "decliners") and physical activity, with 13 self-selection items included [36]. MacDonald et al. (2010) considered the propensity to be in a treatment (i.e., participants in employment who used light rail transit daily) or "control" group (i.e., participants in employment who did not use light rail transit to commute to work) based on sociodemographic characteristics, social and physical environment characteristics and intention to use light rail [33]. MacDonald 


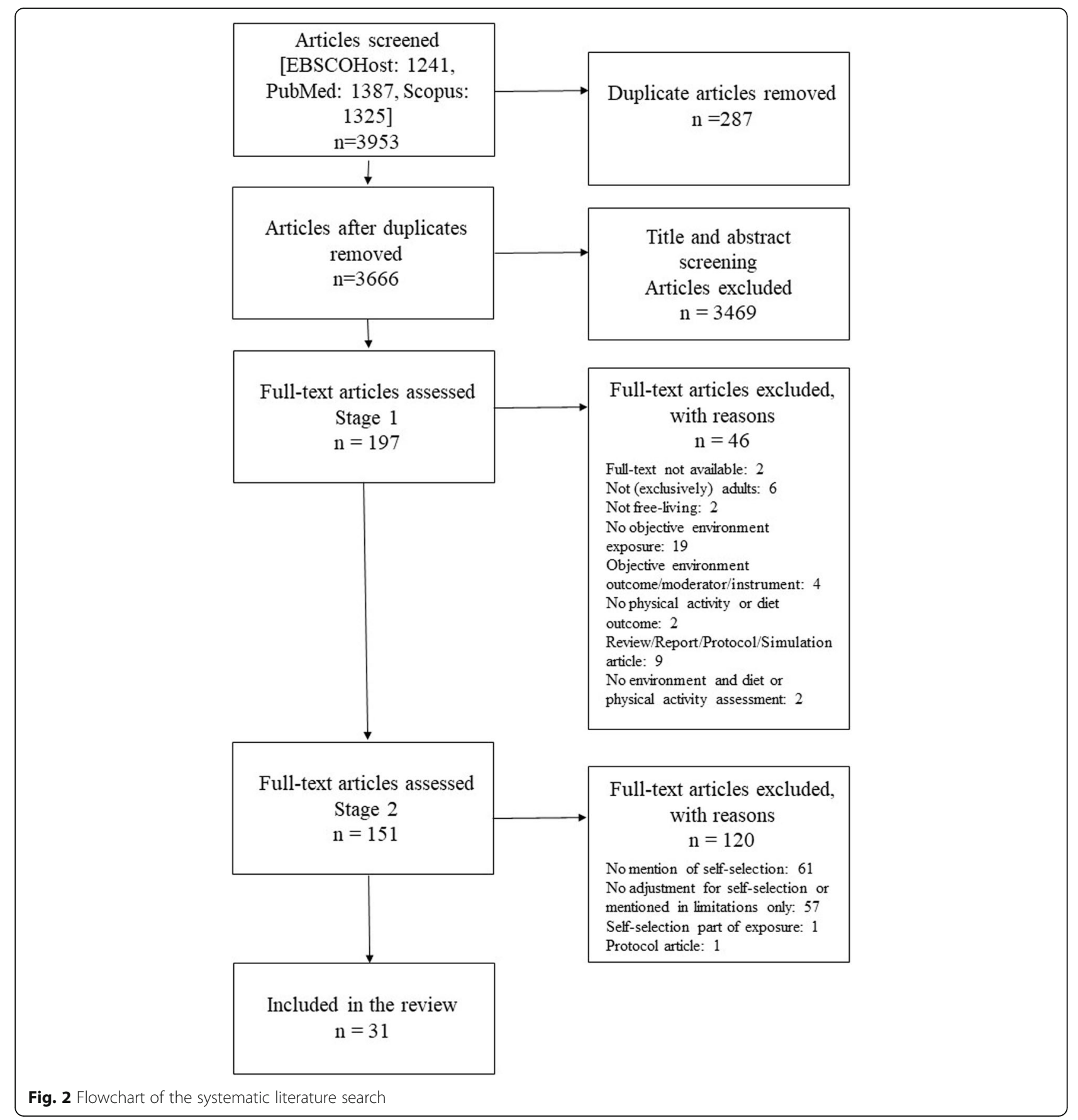

et al. (2010) also employed a pre-post study design to deal with neighbourhood self-selection, discussed further below.

\section{Restricted population}

Four articles placed restrictions on the population of participants considered, in order to deal with neighbourhood self-selection [16, 19-21]. Two articles by the same lead author $[19,20]$ restricted the population to recent Cuban immigrants to Florida, highlighting that this is a population "who overwhelmingly reported little choice in their selection of built environments" [20]. These studies also adjusted for age, gender and education (previously mentioned characteristics that can at least partly account for neighbourhood selection), as well as body mass index, days resident in the USA, and habitual physical activity, when examining associations between built environment characteristics, such as walkability, and physical activity $[19,20]$. Another study restricted the population by only considering a small study area [16]. The fourth article 


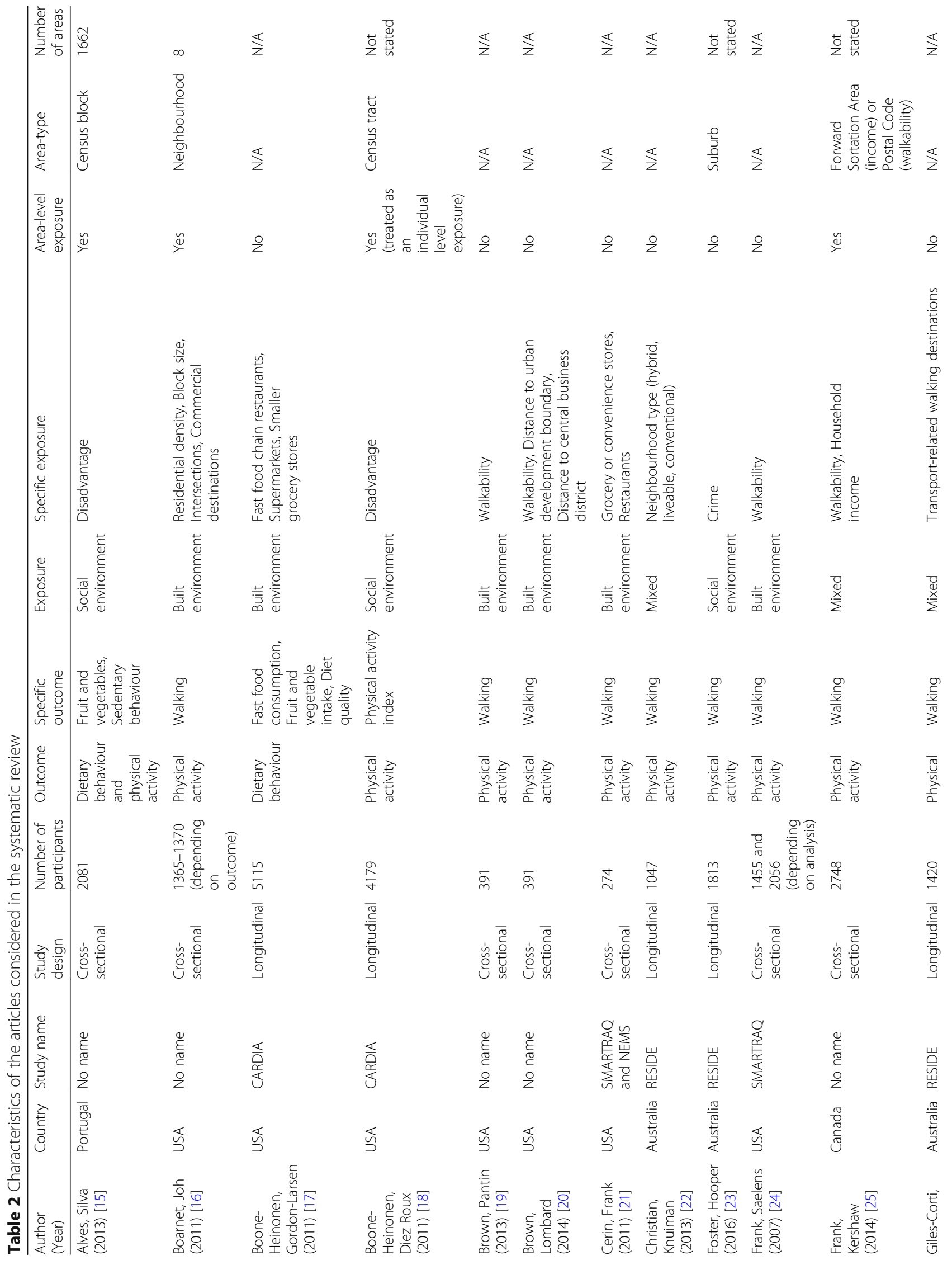




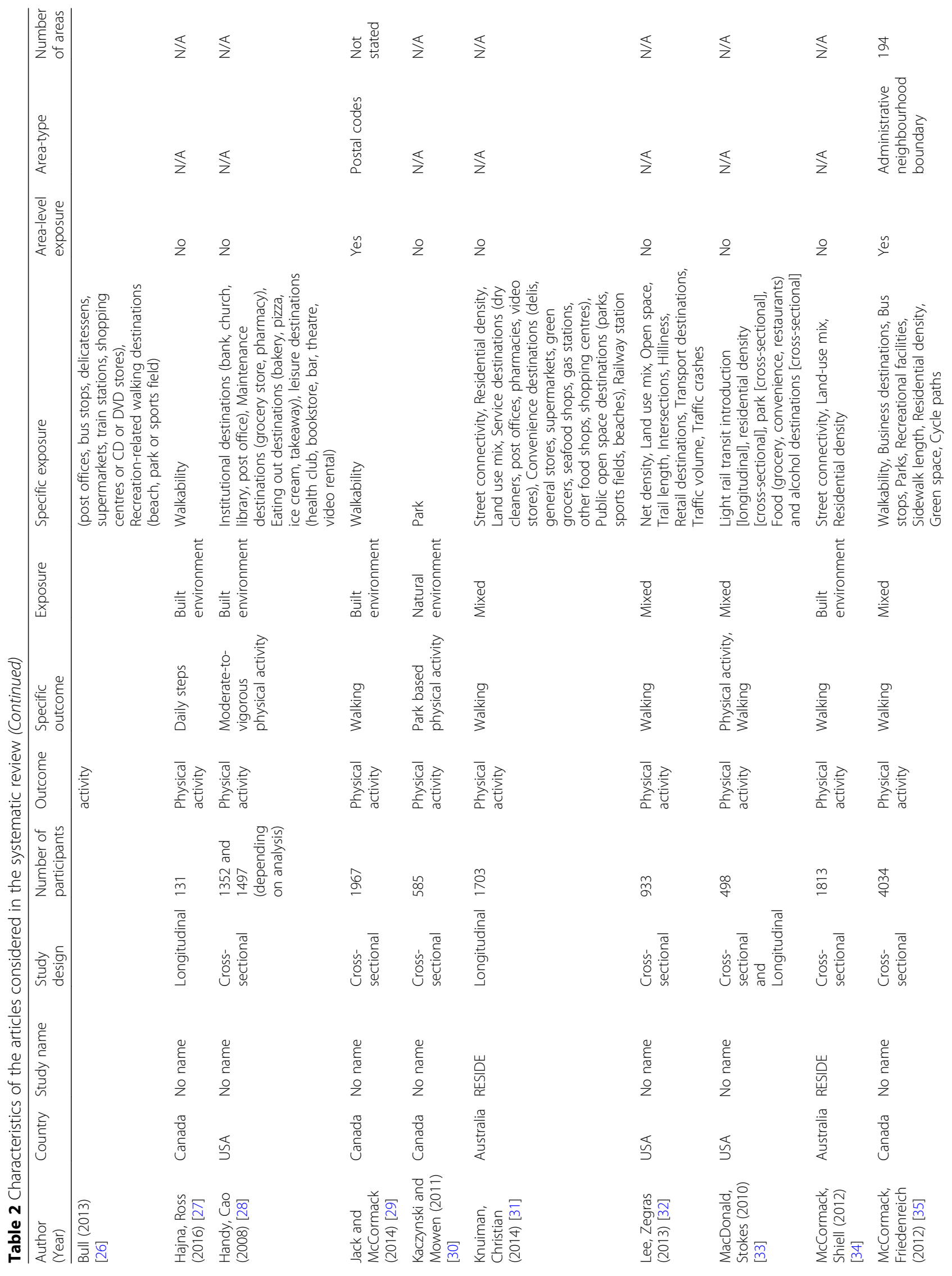




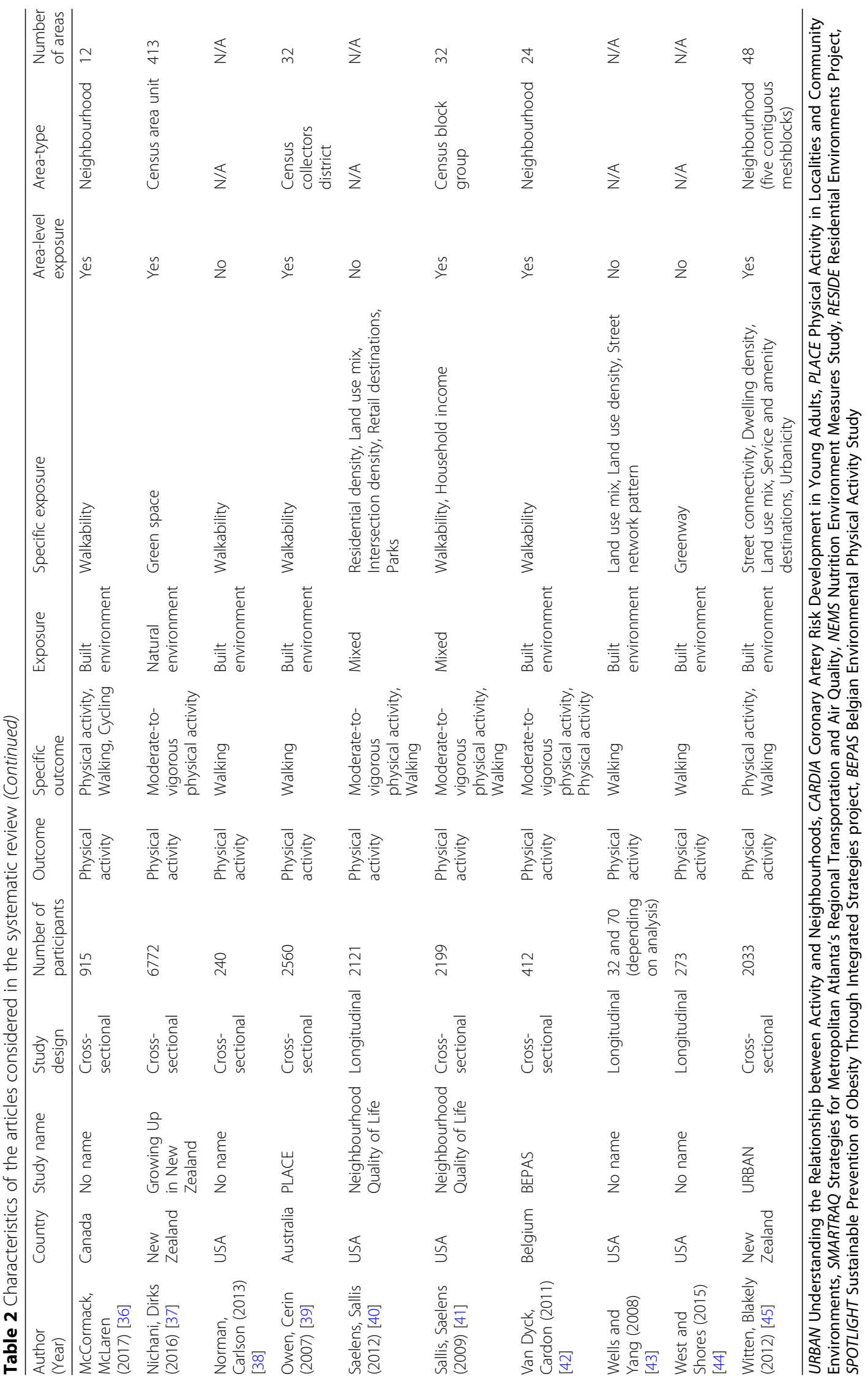


Table 3 Methods used to account for neighbourhood self-selection in the articles considered in the systematic review

\begin{tabular}{|c|c|c|c|c|c|c|c|}
\hline $\begin{array}{l}\text { Author } \\
\text { (Year) }\end{array}$ & $\begin{array}{l}\text { Study } \\
\text { design }\end{array}$ & Outcome & Exposure & $\begin{array}{l}\text { Method to account } \\
\text { for neighbourhood } \\
\text { self-selection }\end{array}$ & $\begin{array}{l}\text { Neighbourhood } \\
\text { self-selection } \\
\text { variable(s) }\end{array}$ & $\begin{array}{l}\text { Items/variables } \\
\text { in derived } \\
\text { neighbourhood } \\
\text { self-selection } \\
\text { variable(s) }\end{array}$ & $\begin{array}{l}\text { Comparison } \\
\text { with and } \\
\text { without self- } \\
\text { selection }\end{array}$ \\
\hline $\begin{array}{l}\text { Alves, Silva } \\
\text { (2013) [15] }\end{array}$ & $\begin{array}{l}\text { Cross- } \\
\text { sectional }\end{array}$ & $\begin{array}{l}\text { Dietary } \\
\text { behaviour } \\
\text { and } \\
\text { physical } \\
\text { activity }\end{array}$ & Disadvantage & Model adjustment & $\begin{array}{l}\text { Sociodemographic } \\
\text { characteristics }\end{array}$ & $\begin{array}{l}3 \text { variables: } \\
\text { i) Age; } \\
\text { ii) Education; } \\
\text { iii) Marital status }\end{array}$ & No \\
\hline $\begin{array}{l}\text { Boarnet, Joh } \\
\text { (2011) [16] }\end{array}$ & $\begin{array}{l}\text { Cross- } \\
\text { sectional }\end{array}$ & $\begin{array}{l}\text { Physical } \\
\text { activity }\end{array}$ & $\begin{array}{l}\text { Residential } \\
\text { density, Block } \\
\text { size, Intersections, } \\
\text { Commercial } \\
\text { destinations }\end{array}$ & $\begin{array}{l}\text { Restricted population } \\
\text { (only consider a small } \\
\text { study area, arguing "If } \\
\text { residential location } \\
\text { choice mostly } \\
\text { determines the study } \\
\text { area where persons live, } \\
\text { but not where along } \\
\text { the corridor residents } \\
\text { live, then travel } \\
\text { behaviour differences } \\
\text { within the corridors } \\
\text { will be due to direct } \\
\text { effects of differences } \\
\text { in the built environment } \\
\text { and business } \\
\text { concentration, and not } \\
\text { residential preferences.") }\end{array}$ & $N / A$ & N/A & No \\
\hline $\begin{array}{l}\text { Boone- } \\
\text { Heinonen, } \\
\text { Gordon- } \\
\text { Larsen } \\
\text { (2011) [17] }\end{array}$ & Longitudinal & $\begin{array}{l}\text { Physical } \\
\text { activity }\end{array}$ & Disadvantage & $\begin{array}{l}\text { Model adjustment and } \\
\text { Fixed effects regression } \\
\text { (Considered both mixed } \\
\text { and fixed effects } \\
\text { regression) }\end{array}$ & $\begin{array}{l}\text { i) } \\
\text { Sociodemographic } \\
\text { characteristics }\end{array}$ & $\begin{array}{l}5 \text { variables: } \\
\text { i) Education; } \\
\text { ii) Income; } \\
\text { iii) Race; } \\
\text { iv) Marital status; } \\
\text { v) Children }\end{array}$ & Yes \\
\hline $\begin{array}{l}\text { Boone- } \\
\text { Heinonen, } \\
\text { Diez Roux } \\
\text { (2011) [18] }\end{array}$ & Longitudinal & $\begin{array}{l}\text { Dietary } \\
\text { behaviour }\end{array}$ & $\begin{array}{l}\text { Fast food chain } \\
\text { restaurants, } \\
\text { Supermarkets, } \\
\text { Smaller grocery } \\
\text { stores }\end{array}$ & Fixed effects regression & N/A & N/A & No \\
\hline $\begin{array}{l}\text { Brown, } \\
\text { Pantin } \\
\text { (2013) [19] }\end{array}$ & $\begin{array}{l}\text { Cross- } \\
\text { sectional }\end{array}$ & $\begin{array}{l}\text { Physical } \\
\text { activity }\end{array}$ & Walkability & $\begin{array}{l}\text { Restricted population } \\
\text { (only considered recent } \\
\text { Cuban immigrants who } \\
\text { overwhelmingly } \\
\text { reported that they did } \\
\text { not select their } \\
\text { neighbourhood based } \\
\text { on built environment } \\
\text { characteristics) }\end{array}$ & N/A & $\mathrm{N} / \mathrm{A}$ & No \\
\hline $\begin{array}{l}\text { Brown, } \\
\text { Lombard } \\
\text { (2014) [20] }\end{array}$ & $\begin{array}{l}\text { Cross- } \\
\text { sectional }\end{array}$ & $\begin{array}{l}\text { Physical } \\
\text { activity }\end{array}$ & $\begin{array}{l}\text { Walkability, } \\
\text { Distance to } \\
\text { urban } \\
\text { development } \\
\text { boundary, } \\
\text { Distance to } \\
\text { central business } \\
\text { district }\end{array}$ & $\begin{array}{l}\text { Restricted population } \\
\text { (only considered recent } \\
\text { Cuban immigrants who } \\
\text { overwhelmingly } \\
\text { reported that they did } \\
\text { not select their } \\
\text { neighbourhood based } \\
\text { on built environment } \\
\text { characteristics) }\end{array}$ & $N / A$ & N/A & No \\
\hline $\begin{array}{l}\text { Cerin, Frank } \\
\text { (2011) [21] }\end{array}$ & $\begin{array}{l}\text { Cross- } \\
\text { sectional }\end{array}$ & $\begin{array}{l}\text { Physical } \\
\text { activity }\end{array}$ & Land use mix & $\begin{array}{l}\text { Restricted population } \\
\text { (limited to middle and } \\
\text { high-income } \\
\text { residents who could } \\
\text { self-select for reasons } \\
\text { other than affordability) }\end{array}$ & $N / A$ & N/A & No \\
\hline $\begin{array}{l}\text { Christian, } \\
\text { Knuiman } \\
\text { (2013) [22] }\end{array}$ & Longitudinal & $\begin{array}{l}\text { Physical } \\
\text { activity }\end{array}$ & $\begin{array}{l}\text { Neighbourhood } \\
\text { type (hybrid, } \\
\text { liveable, } \\
\text { conventional) }\end{array}$ & Model adjustment & $\begin{array}{l}\text { Importance of } \\
\text { characteristics for } \\
\text { living in or moving } \\
\text { to neighbourhood/ } \\
\text { new house }\end{array}$ & $\begin{array}{l}21 \text { items [not provided; } \\
\text { referenced another } \\
\text { article]. Factor analysis } \\
\text { identified } 5 \text { factors: } \\
\text { i) streets are pedestrian } \\
\text { and cycling friendly; } \\
\text { ii) access to services, }\end{array}$ & No \\
\hline
\end{tabular}


Table 3 Methods used to account for neighbourhood self-selection in the articles considered in the systematic review (Continued)

\begin{tabular}{|c|c|c|c|c|}
\hline $\begin{array}{l}\text { Author } \\
\text { (Year) }\end{array}$ & $\begin{array}{l}\text { Study } \\
\text { design }\end{array}$ & Outcome & Exposure & $\begin{array}{l}\text { Method to accour } \\
\text { for neighbourhoo } \\
\text { self-selection }\end{array}$ \\
\hline $\begin{array}{l}\text { Foster, } \\
\text { Hooper } \\
\text { (2016) [23] }\end{array}$ & Longitudinal & $\begin{array}{l}\text { Physical } \\
\text { activity }\end{array}$ & Crime & Model adjustm \\
\hline $\begin{array}{l}\text { Frank, } \\
\text { Saelens } \\
\text { (2007) [24] }\end{array}$ & $\begin{array}{l}\text { Cross- } \\
\text { sectional }\end{array}$ & $\begin{array}{l}\text { Physical } \\
\text { activity }\end{array}$ & $\begin{array}{l}\text { Walkability, } \\
\text { Household } \\
\text { income }\end{array}$ & Model adjustm \\
\hline
\end{tabular}

$\begin{array}{ll}\text { Neighbourhood } & \text { Items/variables } \\ \text { self-selection } & \text { in derived } \\ \text { variable(s) } & \text { neighbourhood } \\ & \text { self-selection } \\ & \text { variable(s) }\end{array}$

\section{Comparison
with and} variable(s)

jobs or place of study; iii) access to school; iv) close to parks and recreational facilities; v) safe, diverse and easy living community. Importance of
characteristics for
living in or moving
to neighbourhood/
new house

i) Importance of characteristics for living in or moving to neighbourhood/ new house, ii) Neighbourhood preference

1 item: i) Importance of safety from crime

10 items in reasons for

moving:

i) Low crime,

ii) Affordability,

iii) Closeness to job,

iv) Near shops and services,

v) Near major roads and

interstates, vi) Ease of

walking, vii) Low

transportation costs,

viii) Near outdoor recreation

ix) Quality of schools, x) Near to public transit.

Principal components analysis identified 1 factor with low transportation costs, near to public transit and ease of walking having highest loads. The average score of these three items was split into quartiles and used as the self-selection variable. 7 trade-offs used to assess preferences: i) walkability vs. commercial-residential land use separation, ii) commute distance vs. residential density, iii) urban vitality vs. low-density and single-use neighbourhoods,

iv) commute distance vs. living on quieter cul-de-sac street, v) availability of alternatives to the car vs. home size, vi) accommodation of automobile vs.

accommodation of pedestrians and cyclists, vii) availability of alternatives to the car vs. neighbourhood privacy. Principal components analysis identified 1 factor. This was normalised and split into quartiles.

Model adjustment

Neighbourhood preference
7 trade-offs used to assess preferences in walkable vs. auto-orientated neighbourhoods: i) Closeness to shops and services; ii) Level of activity and mix of housing; iii) Home size and travel options; iv) Lot size and commute distance; v) Street design and travel options; vi) Public recreation and lot size; vii) Access to 
Table 3 Methods used to account for neighbourhood self-selection in the articles considered in the systematic review (Continued)

\begin{tabular}{llllll}
\hline $\begin{array}{l}\text { Author } \\
\text { (Year) }\end{array}$ & $\begin{array}{l}\text { Study } \\
\text { design }\end{array}$ & Outcome Exposure & $\begin{array}{l}\text { Method to account } \\
\text { for neighbourhood } \\
\text { self-selection }\end{array}$ & $\begin{array}{l}\text { Neighbourhood } \\
\text { self-selection } \\
\text { variable(s) }\end{array}$ & $\begin{array}{l}\text { Items/variables } \\
\text { in derived } \\
\text { neighbourhood } \\
\text { self-selection } \\
\text { variable(s) }\end{array}$
\end{tabular}

$$
\text { variable(s) }
$$

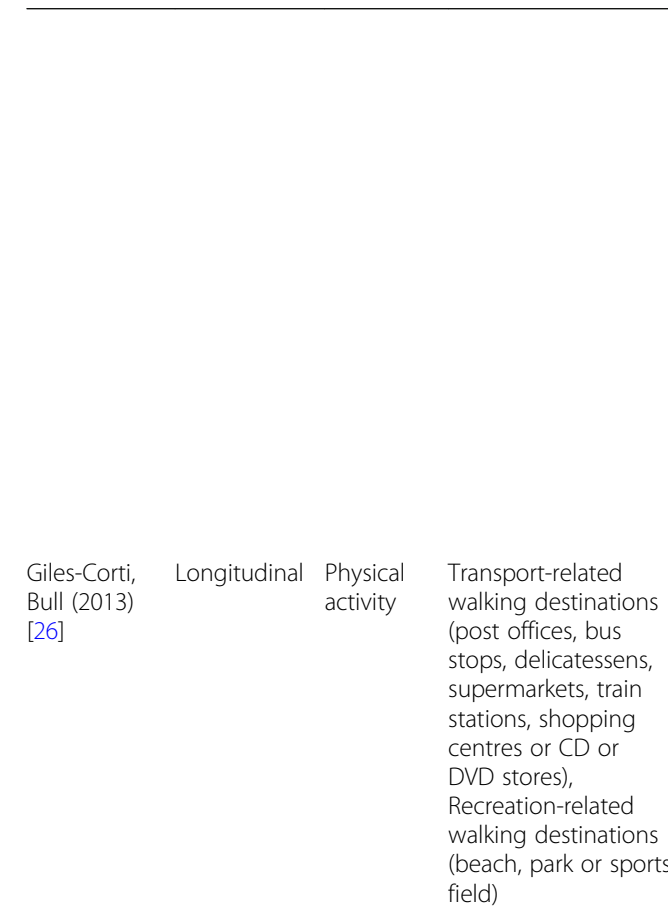

Hajna, Ross Longitudinal Physical Walkability

(2016) [27] activity

Handy, Cao Cross-

(2008) [28] sectional
Physical activity
Model adjustment

characteristics for
living in or moving
to neighbourhood/
new house

new house

Model adjustment

Institutional

destinations (bank,

church, library, post

office), Maintenance

destinations (grocery

store, pharmacy),

Eating out

destinations (bakery,

pizza, ice cream,

takeaway), leisure

destinations (health

club, bookstore, bar,

theatre, video rental)

Residential selfselection

Model adjustment

Importance of neighbourhood/ and size of food stores.

Trade-offs were evaluated using 11-point scales for each of three questions: 1)

"Your neighbourhood preference is ... ", 2) "Indicate

if your current neighbourhood is more like " $\mathrm{A}$ " or " $\mathrm{B}$ " ..." ,

3) "Regarding [the described attributes], the neighbourhood you'd hope to find would be [more like " $\mathrm{A}$ " or " $\mathrm{B}$ "] than your current neighbourhood". Principal component analysis was used to extract a single neighbourhood preference component. This was split into quartiles.

21 items [not provided; referenced another article].

Factor analysis identified 5

factors: i) streets are pedestrian and cycling friendly; ii) access to services, jobs or place of study; iii) access to school; iv) close to parks and recreational facilities: v) safe, diverse, easy living community. These five were included as separate categorical variables (Not important or not important at all/Somewhat important/ Important). In addition, a self-selection scale (not important or somewhat important) used in previous studies was considered.

Residential self-selection: 11 items from the Neighbourhood Quality of Life Study questionnaire (reference but no details provided)

34 items [not all provided]: characteristics when i) Easy access to a regional looking to move to shopping mall, ii) Easy access to downtown, iii) Other to downtown, iii) Other
amenities such as a pool or community centre available nearby, iv) Shopping areas within walking distance, v) Easy access to the freeway, vi) Good public transit service (bus or rail), vii) Good bicycle routes beyond neighbourhood, viii) Sidewalks throughout neighbourhood, ix) Parks and open spaces nearby, x) Quiet neighbourhood, xi) Low crime rate within neighbourhood, xii) Low level of car traffic on neighbourhood streets, xiii) Safe neighbourhood for walking, xiv) Safe neighbourhood for kids to play outdoors, xv) Good street 
Table 3 Methods used to account for neighbourhood self-selection in the articles considered in the systematic review (Continued)

\begin{tabular}{|c|c|c|c|c|c|c|c|}
\hline $\begin{array}{l}\text { Author } \\
\text { (Year) }\end{array}$ & $\begin{array}{l}\text { Study } \\
\text { design }\end{array}$ & Outcome & Exposure & $\begin{array}{l}\text { Method to account } \\
\text { for neighbourhood } \\
\text { self-selection }\end{array}$ & $\begin{array}{l}\text { Neighbourhood } \\
\text { self-selection } \\
\text { variable(s) }\end{array}$ & $\begin{array}{l}\text { Items/variables } \\
\text { in derived } \\
\text { neighbourhood } \\
\text { self-selection } \\
\text { variable(s) }\end{array}$ & $\begin{array}{l}\text { Comparison } \\
\text { with and } \\
\text { without self } \\
\text { selection }\end{array}$ \\
\hline
\end{tabular}

lighting, xvi) Diverse neighbourhoods in terms of ethnicity, race, and age, xvii) Lots of people out and about within my neighbourhood, xviii) Lots of interaction among neighbours, xix) Economic level of neighbours similar to my level, xx) Attractive appearance of neighbourhood, xxi) High level of upkeep in neighbourhood, xxii) Variety in housing styles, xxiii) Big street trees, xxiv) Large backyards, xxv) Large front yards, xxvi) Lots of off-street parking (garages or driveways). Principal components analysis identified six factors: accessibility, physical activity options, attractiveness, outdoor spaciousness, safety, and socialising.

\begin{tabular}{|c|c|c|c|c|}
\hline $\begin{array}{l}\text { Jack and } \\
\text { McCormack }\end{array}$ & $\begin{array}{l}\text { Cross- } \\
\text { sectional }\end{array}$ & $\begin{array}{l}\text { Physical } \\
\text { activity }\end{array}$ & Walkability & Model adjustment \\
\hline
\end{tabular}

Importance of characteristics for living in or moving to neighbourhood/ new house
Physical Park

and Mowen sectional activity

(2011) [30]

$\begin{array}{ll}\text { Knuiman, Longitudinal } & \text { Physical } \\ \text { Christian } & \text { activity }\end{array}$

(2014) [31]

Lee, Zegras Cross-

(2013) [32] sectional

Physical activity

MacDonald, Cross-
Street connectivity, Residential density, Land use mix, Service destinations (dry cleaners, post offices, pharmacies, video stores), Convenience destinations (delis, general stores, supermarkets, green grocers, seafood shops, gas stations, other food shops, shopping centres), Public open space destinations (parks, sports fields, beaches), Railway station

Net density, Land use mix, Open space, Trai length, Intersections, Hilliness, Retail destinations,

Transport volume, Traffic crashes

19 items [not provided]. Principal components analysis identified four factors: access to places that support physical activity, access to local services, sense of community, ease of driving. These were transformed into z-scores.

Model adjustment

Importance of characteristics for living in or moving to neighbourhood/ new house Fixed effects regression N/A N/A

1 item: i) Importance of closeness to open space destinations, Traffic

Model adjustment

Self-selection

Light rail transit
Unclear. Used structural equation modelling to enable the inclusion of latent characteristics to control for self-selection. 
Table 3 Methods used to account for neighbourhood self-selection in the articles considered in the systematic review (Continued)

\begin{tabular}{|c|c|c|c|c|c|c|c|}
\hline $\begin{array}{l}\text { Author } \\
\text { (Year) }\end{array}$ & $\begin{array}{l}\text { Study } \\
\text { design }\end{array}$ & Outcome & Exposure & $\begin{array}{l}\text { Method to account } \\
\text { for neighbourhood } \\
\text { self-selection }\end{array}$ & $\begin{array}{l}\text { Neighbourhood } \\
\text { self-selection } \\
\text { variable(s) }\end{array}$ & $\begin{array}{l}\text { Items/variables } \\
\text { in derived } \\
\text { neighbourhood } \\
\text { self-selection } \\
\text { variable(s) }\end{array}$ & $\begin{array}{l}\text { Comparison } \\
\text { with and } \\
\text { without self- } \\
\text { selection }\end{array}$ \\
\hline $\begin{array}{l}\text { Stokes } \\
\text { (2010) [33] }\end{array}$ & $\begin{array}{l}\text { sectional } \\
\text { and } \\
\text { Longitudinal }\end{array}$ & activity & $\begin{array}{l}\text { introduction } \\
\text { [longitudinal], } \\
\text { residential density } \\
\text { [cross-sectional], park } \\
\text { [cross-sectional], } \\
\text { Food (grocery, } \\
\text { convenience, } \\
\text { restaurants) and } \\
\text { alcohol destinations } \\
\text { [cross-sectional] }\end{array}$ & Quasi-experiment & $\begin{array}{l}\text { Sociodemographic } \\
\text { variables, ii) Plans to } \\
\text { use light rail transit }\end{array}$ & $\begin{array}{l}\text { /baseline characteristics } \\
\text { included } 7 \text { items: i) gender, } \\
\text { ii) race, iii) age, iv) employed, } \\
\text { v) miles to work, } \\
\text { vi) education level, vii) rent }\end{array}$ & \\
\hline $\begin{array}{l}\text { McCormack, } \\
\text { Shiell (2012) } \\
\text { [34] }\end{array}$ & $\begin{array}{l}\text { Cross- } \\
\text { sectional }\end{array}$ & $\begin{array}{l}\text { Physical } \\
\text { activity }\end{array}$ & $\begin{array}{l}\text { Street connectivity, } \\
\text { Land-use mix, } \\
\text { Residential density }\end{array}$ & Propensity score & $\begin{array}{l}\text { i) Importance of } \\
\text { characteristics for } \\
\text { living in or moving } \\
\text { to neighbourhood/ } \\
\text { new house; ii) } \\
\text { Number of years in } \\
\text { current } \\
\text { neighbourhood; iii) } \\
\text { Sociodemographic } \\
\text { characteristics }\end{array}$ & $\begin{array}{l}19 \text { items for characteristics: } \\
\text { i) Affordability, ii) Proximity to } \\
\text { parks, iii) Proximity to job/ } \\
\text { school, iv) Proximity to transit, } \\
\text { v) Proximity to stores/services, } \\
\text { vi) Ease of walking, vii) Sense } \\
\text { of community, viii) Safety } \\
\text { from crime, ix) Proximity to } \\
\text { recreation facilities, x) Access } \\
\text { to highways, xi) Attractive } \\
\text { streets, xii) Proximity to } \\
\text { family/friends, xiii) Views of } \\
\text { scenery (e.g., mountains), } \\
\text { xiv) Cleanliness of streets, } \\
\text { xv) Proximity to downtown, } \\
\text { xvi) Proximity to trails, } \\
\text { xvii) Places to be physically } \\
\text { active, xviii) Places to walk } \\
\text { cycle to, xix) Ease of driving. } \\
\text { Sociodemographic } \\
\text { characteristics: i) home } \\
\text { ownership status, ii) gender, } \\
\text { iii) age, iv) education, } \\
\text { v) number of dependents < } \\
18 \text { years at home }\end{array}$ & No \\
\hline $\begin{array}{l}\text { McCormack, } \\
\text { Friedenreich } \\
\text { (2012) }[35]\end{array}$ & $\begin{array}{l}\text { Cross- } \\
\text { sectional }\end{array}$ & $\begin{array}{l}\text { Physical } \\
\text { activity }\end{array}$ & Walkability & Model adjustment & $\begin{array}{l}\text { Importance of } \\
\text { characteristics for } \\
\text { living in or moving } \\
\text { to neighbourhood/ } \\
\text { new house }\end{array}$ & $\begin{array}{l}21 \text { items [not provided; } \\
\text { referenced another article]. } \\
\text { Factor analysis identified } 5 \\
\text { factors: i) Pedestrian and } \\
\text { cycling friendly streets; } \\
\text { ii) Accessible services for daily } \\
\text { living; iii) Accessible schools } \\
\text { or places of study; } \\
\text { iv) Accessible parks and } \\
\text { recreation facilities; } \\
\text { 5) Housing affordability and } \\
\text { choice. Factors included as } \\
\text { covariates in the models. }\end{array}$ & Yes \\
\hline $\begin{array}{l}\text { McCormack, } \\
\text { McLaren } \\
(2017) \text { [36] }\end{array}$ & $\begin{array}{l}\text { Cross- } \\
\text { sectional }\end{array}$ & $\begin{array}{l}\text { Physical } \\
\text { activity }\end{array}$ & $\begin{array}{l}\text { Walkability, Business } \\
\text { destinations, Bus } \\
\text { stops, Parks, } \\
\text { Recreational facilities, } \\
\text { Sidewalk length, } \\
\text { Residential density, } \\
\text { Green space, Cycle } \\
\text { paths }\end{array}$ & Propensity score & $\begin{array}{l}\text { Importance of } \\
\text { characteristics for } \\
\text { living in or moving } \\
\text { to neighbourhood/ } \\
\text { new house }\end{array}$ & $\begin{array}{l}13 \text { items: i) Proximity to } \\
\text { transit, ii) Proximity to } \\
\text { recreational destinations, } \\
\text { iii) Proximity to non- } \\
\text { recreational destinations, } \\
\text { iv) Proximity to work, } \\
\text { v) Proximity to schools, } \\
\text { vi) Proximity to downtown, } \\
\text { vii) Access to highways and } \\
\text { major roads, viii) Access to } \\
\text { community associations, } \\
\text { ix) Sense of community, } \\
\text { x) Attractiveness, } \\
\text { xi) Cleanliness of streets, } \\
\text { xii) Housing type variety, } \\
\text { xiii) quality of recreational } \\
\text { facilities. Responses to each } \\
\text { item were collapsed from } \\
\text { "not at all", "somewhat" and }\end{array}$ & No \\
\hline
\end{tabular}


Table 3 Methods used to account for neighbourhood self-selection in the articles considered in the systematic review (Continued)

\begin{tabular}{lllllll}
\hline $\begin{array}{l}\text { Author } \\
\text { (Year) }\end{array}$ & $\begin{array}{l}\text { Study } \\
\text { design }\end{array}$ & Outcome & Exposure & $\begin{array}{l}\text { Method to account } \\
\text { for neighbourhood } \\
\text { self-selection }\end{array}$ & $\begin{array}{l}\text { Neighbourhood } \\
\text { self-selection } \\
\text { variable(s) }\end{array}$ & $\begin{array}{l}\text { Items/variables } \\
\text { in derived } \\
\text { neighbourhood } \\
\text { self-selection } \\
\text { variable(s) }\end{array}$ \\
\end{tabular}

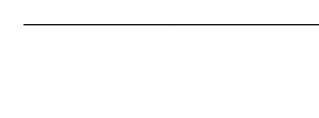

\begin{tabular}{|c|c|c|c|c|c|}
\hline $\begin{array}{l}\text { Nichani, } \\
\text { Dirks }\end{array}$ & $\begin{array}{l}\text { Cross- } \\
\text { sectional }\end{array}$ & $\begin{array}{l}\text { Physical } \\
\text { activity }\end{array}$ & Green space & Model adjustment & $\begin{array}{l}\text { Neighbourhood } \\
\text { preference }\end{array}$ \\
\hline
\end{tabular}

"very important" into "not important" and "important".

Dirks sectional activity

(2016) [37]

$\begin{array}{lll}\text { Norman, } & \begin{array}{l}\text { Cross- } \\ \text { Carlson }\end{array} & \text { Physical Walkability } \\ \text { sectional } & \text { activity } & \end{array}$

(2013) [38]

$\begin{array}{lll}\text { Owen, Cerin } & \text { Cross- } & \text { Physical Walkability } \\ \text { (2007) [39] } & \text { sectional } & \text { activity }\end{array}$

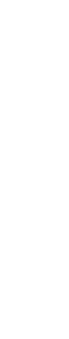

$\begin{array}{ll}\text { Saelens, } \quad \text { Longitudinal } & \begin{array}{l}\text { Physical } \\ \text { Sallis }\end{array} \\ \text { (2012) [40] } & \end{array}$

Residential density, Land use mix, Intersection density, Retail destinations, Parks

$\begin{array}{llll}\text { Sallis, } & \text { Cross- } & \text { Physical } & \text { Walkability, } \\ \text { Saelens } & \text { sectional } & \text { activity } & \text { Household income }\end{array}$

Saelens (2009) [41]
Model adjustment

characteristics for
living in or moving
to neighbourhood/
new house; ii)
Neighbourhood
preference

Propensity scores were created.

1 item: "Why do you live in this neighbourhood?: I like the local lifestyle." No/Yes. Local lifestyle included access to community resources (e.g. green space, recreational facilities, public transport, shopping, education, healthcare, social and cultural facilities).

4 items in moving: i) Ease of walking; ii) Near public transit; iii) Near shops and services; iv) Near outdoor recreation. The average rating of these items, all measured on 5-point scales, was split at the median to categorise as low/ high importance of walkability. 3 items in preference: i) residential density; ii) land use; iii) street connectivity. The average rating of these items, all measured on 11-point scales, was split at the median to categorise as low/high preference for a high-walkability neighbourhood.

Importance of $\quad 4$ items: i) Closeness to job or characteristics for school; ii) Closeness to public living in or moving transportation; iii) Desire for to neighbourhood/ nearby shops and services; new house

iv) Ease of walking. The average rating of these items, all on 5-point scales, was used as neighbourhood selfselection measure.

Importance of $\quad 3$ items [chosen based on characteristics for factor analysis of 11 residential living in or moving selection items]: i) Closeness to neighbourhood/ to public transportation: new house

ii) Desire for nearby shops and services; iii) Ease of walking. The average rating of these items, all on 5-point scales, was used as residential selection variable.

Importance of characteristics for 3 items: i) Desire for nearby shops and services; ii) Ease living in or moving of walking; iii) Closeness to to neighbourhood/ recreational facilities. The new house average rating of these items, [scale not provided but reference to paper provided] was used as measure of walkability-related self-selection of neighbourhoods.

Importance of characteristics for living in or moving to neighbourhood/ new house
21 items: i) House price; ii) Importance of living in city living in a quiet neighbourhood; iv-vii) Social centre; iii) Importance of
No 
Table 3 Methods used to account for neighbourhood self-selection in the articles considered in the systematic review (Continued)

\begin{tabular}{|c|c|c|c|c|c|c|c|}
\hline $\begin{array}{l}\text { Author } \\
\text { (Year) }\end{array}$ & $\begin{array}{l}\text { Study } \\
\text { design }\end{array}$ & Outcome & Exposure & $\begin{array}{l}\text { Method to account } \\
\text { for neighbourhood } \\
\text { self-selection }\end{array}$ & $\begin{array}{l}\text { Neighbourhood } \\
\text { self-selection } \\
\text { variable(s) }\end{array}$ & $\begin{array}{l}\text { Items/variables } \\
\text { in derived } \\
\text { neighbourhood } \\
\text { self-selection } \\
\text { variable(s) }\end{array}$ & $\begin{array}{l}\text { Comparison } \\
\text { with and } \\
\text { without self } \\
\text { selection }\end{array}$ \\
\hline
\end{tabular}

variable(s)

/emotional reasons (e.g. living close to family and friends); viii-xxi) Walkability related items (e.g. importance of closeness to shops, closeness to work/school, traffic safety, amount and quality of sidewalks/footpaths). All items were scored on a 5-point scale. A single variable was created but it is not clear how this was defined. Those scoring higher than the median were considered to have walkability as an important reason for

$\begin{array}{lll}\text { Wells and } & \text { Longitudinal } & \begin{array}{l}\text { Physical } \\ \text { Yang }\end{array} \\ \text { (2008) [43] } & \text { activity } & \begin{array}{l}\text { Land use mix, Land } \\ \text { use density, Street } \\ \text { network pattern }\end{array}\end{array}$

West and

Shores

(2015) [44]

Witten,

Blakely

(2012) [45]

\begin{tabular}{|c|c|c|}
\hline Longitudinal & $\begin{array}{l}\text { Physical } \\
\text { activity }\end{array}$ & Greenway \\
\hline $\begin{array}{l}\text { Cross- } \\
\text { sectional }\end{array}$ & $\begin{array}{l}\text { Physical } \\
\text { activity }\end{array}$ & $\begin{array}{l}\text { Street connectivity, } \\
\text { Dwelling density, } \\
\text { Land use mix, Service } \\
\text { and amenity } \\
\text { destinations, } \\
\text { Urbanicity }\end{array}$ \\
\hline
\end{tabular}

Quasi-experiment (examine post-move pre-move change in exposure on post-move outcome controlling for pre-move outcome)

Quasi-experiment control group)

Model adjustment
N/A neighbourhood selection.
No

N/A

N/A

8 sociodemographic variables:

i) Age; ii) Sex; iii) Ethnicity;

iv) Marital status; v) Household

income; vi) Educational qualifications; vii) Occupation; viii) Household car access. 2 items: i) Prefer lower-density suburban neighbourhood suburban or urban environment located 10-15 min by car from common destinations or a higherdensity urban neighbourhood with most destinations accessible on foot or by public transportation within 10-15 min; ii) Strength of preference for suburban or urban environment. Responses were combined as: strongly prefer walkable, moderately prefer walkable, neutral, moderately prefer less walkable, strongly prefer less walkable. restricted the population to only consider those who could self-select, namely those of middle and high-income whose choice was not restricted for financial reasons [21].

\section{Fixed effects regression}

Three articles used fixed effects regression to deal with neighbourhood self-selection in their longitudinal analyses [17, 18, 31]; one article used both this approach and mixed models with model adjustment [18]. These articles also included potential time-varying confounders in their models, such as income, marriage and children, although none included a measure of neighbourhood preference or reasons for living in current neighbourhood, such as those described in the model adjustment section.

\section{Pre-post design}

Three articles used a pre-post longitudinal design to deal with neighbourhood self-selection [33, 43, 44]. One study used a quasi-experimental pre-post design with a comparison group, with a 1 year follow-up after the introduction of a greenway [44]. Another article employed a pre-post design among a small subsample of participants who moved to a new neighbourhood, to examine differences in 
pre- versus post-move physical activity associated with a changed environment [43]. The authors asserted that selfselection was addressed as the sample consisted of women partnered with a housing program who did not have a choice between neighbourhood types as only one neighbourhood was built within each region. The third study assessed the impact of the introduction of light-rail transit on physical activity, adopting a pre-post design and utilising propensity scores, but without a comparison group [33].

\section{Impact of accounting for self-selection}

Twelve articles compared results of analyses that accounted for neighbourhood self-selection with results of analyses that did not (Table 3). Most (10/12) had used a model adjustment approach, adjusting for measures of neighbourhood self-selection, and thus compared models with and without adjustment for self-selection variable(s) [26, 27, 30 , $32,34,37,39,41,42,45]$.

Three of these 12 articles presented results from one model only, either with or without adjustment for neighbourhood self-selection, asserting in the results section that adjustment for neighbourhood self-selection had little effect on findings [27, 32], or that results were attenuated consequent to adjustment [30]. Six articles presented results for models both with and without adjustment, indicative of only small changes in coefficients or effect estimates for the exposure(s) of interest after adjustment [26, 34, 37, 39, 41, 45]. In one article examining neighbourhood walkability and physical activity, rather than present findings with and without adjustment, results were presented for the full sample of participants in addition to only those with high neighbourhood selfselection (i.e., those for whom walkability characteristics were important in their selection of neighbourhood) [42]. The results were similar in both sets of analyses.

Two articles assessed the impact of accounting for neighbourhood self-selection by comparing findings from fixed effects regression models to those from mixed models [18, 31]. Knuiman et al. (2014) highlighted that the findings from fixed effects regression were similar to those of the mixed model (and to a model fitted using generalised estimating equations which was also considered) [31]. Boone-Heinonen reported that slightly different results were produced depending on the approach taken, highlighting that confounding by unmeasured time-invariant confounders (such as neighbourhood self-selection) was minimal among black participants and stronger among white participants, but that the direction of the effect was consistent [18].

\section{Discussion}

This review examined methods used to account for neighbourhood self-selection in studies examining associations between the built, natural and social environment on adult physical activity and dietary behaviours. In the following we provide a summary of the approaches used, an outline of the limitations of these approaches, a discussion of the variation in study findings due to accounting for neighbourhood self-selection, and an overview of other approaches that may be considered.

\section{Summary and limitations of approaches used to account for neighbourhood self-selection}

In our review, the most common approach used to account for neighbourhood self-selection was model adjustment. The main drawback of the model adjustment approach is that this assumes that all of the important characteristics of neighbourhood self-selection are not only accurately measured and taken into account, but also that these are valid measures of self-selection. This may not be the case, particularly among those that were solely reliant on individual characteristics (e.g., age, sex) as proxies for neighbourhood self-selection, or those which only accounted for one aspect of neighbourhood self-selection deemed important to the exposure of interest. While individual characteristics such as age and sex may influence choice of neighbourhood, requiring accounting for in analyses, they are unlikely to be the only characteristics that influence neighbourhood choice. Analyses only adjusting for selected socio-demographic characteristics assume that only these characteristics influence neighbourhood selection. This ignores the fact that other sociodemographic characteristics, such as the presence of children in the household, as well as individual preferences, are likely to influence choice. Findings may be biased if other important characteristics that influence both the environmental exposure and the outcome are not accounted for. Therefore, it is important that researchers are cautious when identifying neighbourhood self-selection characteristics. If some of these characteristics are unmeasured, researchers should acknowledge this as a limitation of their study, noting that findings may be biased.

Regarding the validity of indicators of neighbourhood self-selection, a key challenge is the temporal ordering of variables in a causal sequence, an issue often challenging to assess given most studies are cross-sectional. For example, in a cross-sectional study examining the effect of park availability on physical activity, the importance of residing close to open space (e.g., parks) was assessed as an indicator of neighbourhood self-selection for participants' choices for moving to their neighbourhood [30]. While this seems reasonable, it is possible that, for individuals already undertaking high levels of physical activity prior to moving, these existing high levels of physical activity would subsequently relate both to residing near open space and continued high levels of physical activity. Therefore, study results suggesting that greater park 
availability is related to physical activity behaviour, even if independent of a given preference to reside close to open space, may not wholly account for self-selection issues which should ideally be assessed temporally: retrospectively for cross-sectional studies, and prospectively for longitudinal studies.

The above example is supported by the extent of variation we uncovered in the characteristics used to account for neighbourhood self-selection. It was not obvious that any of the variables used were derived through application of an explicitly stated sociobehavioural theory. Whilst it is not the purpose of this article to explain social-behavioural theories that may apply, it should go without saying that population health research demands theoretical underpinnings [46, 47]. Theory is highly relevant to variable specification in research on environments and health, given behaviour can be explained in terms of a reciprocal interaction between cognitive, behavioural, and environmental determinants $[48,49]$. A greater use of theory in variable selection would provide more support for defensible choices and, correspondingly, reduce ad hoc selection associated with large variations in choices made. This creates confusion about what should be measured to account for neighbourhood self-selection in future studies. Statistical attempts to account for neighbourhood self-selection that are devoid of theory-driven specifications of relevant measures may increase the potential for residual confounding and generate biased estimates of associations of interest. Researchers examining the effects of neighbourhood environment exposures on health-related behaviour should clearly define which attributes are most relevant and important to assess as predictors of neighbourhood self-selection.

Beyond model adjustment, propensity scores were also used to account for neighbourhood self-selection, although much less frequently than standard variable adjustment in regression models. Propensity scores are commonly used when dealing with a binary exposure (i.e., where there is an exposed and unexposed group), with a propensity score defined as the conditional probability of receiving the exposure given the observed covariates [50]. If it can be assumed that there are no unmeasured confounders (which may be infeasible - see above), then accounting for propensity scores (either via matching, stratification, as a covariate in model adjustment, or inverse-probability weighting) can enable estimation of the causal effect of the exposure. Thus, as with the model adjustment approach, propensity scores can only prevent bias from neighbourhood self-selection if all potential neighbourhood self-selection indicators are valid, measured accurately and reflected in the propensity score.

A third method used to deal with neighbourhood selfselection was to restrict the population under consideration. As argued by Brown et al. [20] and Brown et al. [19] in their studies restricted to recent immigrants, this approach is perhaps appropriate if the population considered truly does not have the ability to choose where they live. However, restriction of other populations, such as middle- and high-income groups, is unlikely to be sufficient to account for neighbourhood self-selection if the investigators do not also examine and account for the preferences that guided the particular choice of neighbourhood. Furthermore, it is questionable to assume that restriction to a particular small geographical area deals with neighbourhood selfselection, as was the case in one article considered in this review. In using this approach, Boarnet et al. (2011) argued that self-selection relates more to the area, or neighbourhood, in which people live, rather than a precise residential location in that neighbourhood [16]. However, this ignores the fact that there may be timevarying neighbourhood characteristics; such that the reasons people chose to live in, or continue to live in, a given neighbourhood may vary depending on their length of residence. For example, recent residents may have chosen to move to a particular neighbourhood due to the accessibility of resources (which may have been non-existent for earlier residents), while early residents may have moved there due to affordability of property (which may now be unaffordable for many aspiring residents). Finally, the restricted population approach is not appropriate for assessing the effect of a neighbourhood environment attribute on a health-related behaviour in the broader population, because it limits the generalisability of the findings to the particular sub-group analysed.

Longitudinal studies offer the best potential for observational studies to address how changes in the environment influence changes in behaviour. However, addressing neighbourhood self-selection prior to or during such studies remains a challenge. One approach used was to conduct within-person analyses of change using fixed effects regression which can account for any time-invariant confounding, irrespective of whether it was measured. This approach to analysing longitudinal data can be used to answer questions about how changes in an exposure affect changes in an outcome [51]. As this is a within-individual analytical approach, both measured and unmeasured time-invariant confounders such as neighbourhood selfselection, are accounted for without the need to explicitly include them in the model. This means that if the reasons for living in a neighbourhood do not change over time, these are accounted for by using this method, whether or not they were measured. Although this appears advantageous, it is perhaps unrealistic to assume that neighbourhood preference does not change over the life course. Individual preferences and reasons for choosing to reside 
in a particular neighbourhood may differ dependent on life stage. For example, choosing to reside near good schools may become important for those with young children, while residing in more walkable neighbourhoods may become more important as individuals age. Furthermore, fixed effects regression specifically assesses both changes in the exposure and outcome. Therefore, if there is little change in the neighbourhood environment exposure, or the outcome, over the time period of the study then fixed effects regression is not a suitable approach to adopt. As highlighted by Grafova et al. [52], this method requires longitudinal data covering a long period of time to ensure sufficient variation. Often, unfortunately, this is not available in neighbourhood and health studies [18].

Studies conducted over time can allow the use of quasi- or natural-experimental designs to assess how change influences behaviour. Of the pre-post studies considered in this review, only one had a comparator group that did not experience the change in environment. A comparison group is required to ensure that any changes over time are not attributable to another factor (or factors) unrelated to the neighbourhood environment that changed over that period. Furthermore, although a quasi-experiment enables assessing how change in an environmental characteristic shapes change in behaviour, the absence of randomisation to experimental conditions does require accounting for potential confounders in analyses. Such variables could include measures of neighbourhood self-selection. Finally, this review identified few natural experiments in this area despite recognition that such designs are important and needed to improve inference on neighbourhood effects on health [53-55]. This may be due to the practical challenges of collecting suitable pre-change data when researchers become aware of the environmental change. However, as discussed by Heinen et al., although quasior natural-experiments are recommended to aid in understanding the impact of neighbourhood features on behaviours, these still pose methodological challenges relating to neighbourhood self-selection. Residential relocation during the study, for example, poses a particular problem for quasi- or natural experiments and must be considered when undertaking analyses [56].

\section{Impact of adjustment for neighbourhood self-selection on findings}

Although an aim of this review was to examine the scope of variation in the study findings after accounting for neighbourhood self-selection, unfortunately it was unclear what the impact of adjusting for neighbourhood self-selection was. Few studies described findings with and without accounting for self-selection. Of those studies that reported results both ways, marginal changes in the parameter estimates and thus minor changes in study conclusions, cannot be interpreted as meaning that self-selection was fully accounted for and had little impact. Providing both models can assist understanding of how the estimated effects differed dependent on adjustment, but unfortunately, as highlighted by Oakes, it is not possible to identify which neighbourhood selfselection variables are important to account for in the analysis [57]. Thus, it is not possible to argue an absence of residual confounding.

\section{Accounting for neighbourhood self-selection in physical activity and dietary behaviour research}

It is notable that most articles identified in this review considered physical activity outcomes, with very few considering dietary behaviour outcomes. This could be because neighbourhood self-selection is simply not considered in this field, or that it is perceived to be of less importance in neighbourhood environment and dietary behaviour research than in physical activity research. However, this ignores the potential for the food environment to be an important aspect of neighbourhood selection or preference. It is possible that individuals desire to live in neighbourhoods where they have a range of food outlets. This may be particularly true of those with a preference for consuming meals out and takeaway foods. Therefore, the possibility of neighbourhood selfselection influencing associations in studies of dietary behaviour should not be overlooked. Future research is needed to examine the influence of neighbourhood selfselection in this area.

\section{Other approaches for dealing with neighbourhood self- selection}

Although emphasised as necessary to understand neighbourhood environment effects on physical activity and dietary behaviour, it is clearly challenging to obtain longitudinal or quasi-experimental data in this field. This means that a continued predominance of cross-sectional research is likely. Unfortunately, this has major implications on our ability to establish the temporal ordering of the relationships under consideration and thus to more convincingly account for self-selection, even if applying theory to determine suitable indicators of self-selection to account for. Hence other approaches for accounting for neighbourhood self-selection suitable for use in cross-sectional research are required. Use of instrumental variables is one such promising approach, as it can deal with time-invariant as well as time-varying confounders [12]. An instrumental variable is associated with the exposure of interest and associated with the outcome only through that exposure. This technique has been used in other areas of neighbourhood environment and health research. For example, Bilger and Carrieri used neighbourhood urbanisation as an instrument 
when examining the association between neighbourhood problems and health [58], while Zick et al. used multiple instrumental variables (the number of churches, number of schools and proportion of the neighbourhood under 16 years of age) to examine the association between neighbourhood walkability and body mass index [59]. Although offering potential for research on neighbourhood environment and physical activity or dietary behaviour research, identifying suitable instrumental variables can be challenging as it is difficult to identify a variable that is only associated with the outcome through that particular environmental exposure. For example, it is likely that neighbourhood urbanisation, considered an instrumental variable by Bilger and Carrieri [58], could in addition to leading to neighbourhood problems, also lead to increased access to services, such as recreational facilities or supermarkets, which have been found to be associated with health. Therefore, any association between neighbourhood urbanisation and heath identified may not be due to neighbourhood problems as hypothesised but may be due to other alternative pathways.

\section{Strengths and limitations}

Strengths of this review include a priori registration and reporting according to PRISMA; extensive pilot work to generate final search terms; and multiple reviewers used at each stage. The search strategy was limited to articles published in the English language and, thus, may not have included all relevant papers. By only including articles that explicitly referred to the use of methods dealing with neighbourhood self-selection, we may have missed other relevant articles which considered approaches for dealing with unmeasured confounders. Furthermore, as this review explicitly included search terms relating to neighbourhood self-selection, to identify methods used to handle this problem, the findings are not generalisable to the broader literature on objective environmental associations with physical activity and dietary behaviour. Articles that did not adjust for neighbourhood selfselection and did not mention it as a limitation did not appear in this search. In addition, this review only considered objective environmental exposures, not perceived exposures. Perceived measures become conflated with neighbourhood self-selection measures when participants report the reasons they live in particular neighbourhoods based on their perceptions of what is in their local environment (same-source bias).

Finally, like all systematic reviews, our analysis was conducted over a specific time period and developments and changes in the field that have occurred subsequently will not be reflected. While there is no strong indication in the research literature of rapid advances in methods in this space since 2017, a follow-up review should be undertaken in the future.

\section{Conclusions}

Methods to account for neighbourhood self-selection are under-developed in research exploring links between neighbourhood environments and physical activity and dietary behaviour outcomes. Although adjusting for measured neighbourhood preference or choice attributes has the potential to reduce bias, it may be important to consider adjustment for multiple items. Future studies should consider appropriate neighbourhood self-selection measures for the environment-behaviour association under examination. Those using adjustment should: 1 ) provide estimates of associations with and without adjustment for neighbourhood self-selection; 2) consider temporality in the measurement of alleged self-selection variables relative to the timing of the environmental exposure and outcome behaviours in longitudinal designs; and 3) also carefully consider the theoretical plausibility of presumed pathways, and bi-directional relationships, in cross-sectional research where causal direction is impossible to establish. This will help gain a greater understanding of the impact of adjustment. Instrumental variables provide promise for dealing with neighbourhood self-selection, but these are not without their own challenges. Finally, longitudinal studies over longer periods, or quasi-experiments with appropriate comparators, may provide the most promise to understand how the neighbourhood environment influences these behaviours. However, ultimately, regardless of study design, it is recommended that future research in this field collects comprehensive information relating to neighbourhood choice and preference, as well as individual characteristics relating to these.

\section{Supplementary information}

Supplementary information accompanies this paper at https://doi.org/10. 1186/s12966-020-00947-2.

Additional file 1: Table S1. Search terms considered in initial search.

\section{Abbreviations}

PRISMA: Preferred Reporting Items for Systematic Reviews and MetaAnalyses; RESIDE: Residential environments

\section{Acknowledgements}

The authors would also like to thank our two research assistants, Ricki Minter and Ekaterina Woods, for their assistance with article screening for this review.

\section{Authors' contributions}

KEL led the review and searching process, conducted the data extraction and led the writing of the article. KEL and LET reviewed the full text articles for self-selection criteria. TLK reviewed articles in the case of disagreements. All authors contributed to the review plan, searching process, article draft and approved the final version for submission.

\section{Funding}

This work was supported by an Australian Research Council Discovery Project Grant [DP 170100751]. RB is supported by an Australian Research Council Future Fellowship [FT 150100131]. SRW was supported by the Medical Research Council (Unit Programme number U105292687). The other 
authors declare they have no actual or potential competing financial interests. These funding sources had no role in conceptualising, designing or conducting this study.

\section{Availability of data and materials}

All data generated or analysed during this study are included in this published article.

\section{Ethics approval and consent to participate}

This study is a systematic review. No ethics approval was required to conduct this review.

\section{Consent for publication}

Not applicable.

\section{Competing interests}

The authors declare that they have no competing interests.

\section{Author details}

${ }^{1}$ School of Exercise and Nutrition Sciences, Institute for Physical Activity and Nutrition (IPAN), Deakin University, Geelong, Australia. ${ }^{2}$ Clinical Epidemiology and Biostatistics Unit, Murdoch Children's Research Institute, Melbourne, Australia. ${ }^{3}$ Department of Paediatrics, The University of Melbourne, Melbourne, Australia. ${ }^{4}$ Centre for Health Equity, Melbourne School of Population and Global Health, The University of Melbourne, Melbourne, Australia. ${ }^{5}$ Medical Research Council Biostatistics Unit, University of Cambridge, Cambridge, UK. ${ }^{6}$ Health Research Institute, University of Canberra, Canberra, Australia. ${ }^{7}$ Department of Medicine, St Vincent's Hospital, The University of Melbourne, Fitzroy, Victoria, Australia.

\section{Received: 30 September 2019 Accepted: 20 March 2020} Published online: 01 April 2020

\section{References}

1. Daniel M, Moore S, Kestens Y. Framing the biosocial pathways underlying associations between place and cardiometabolic disease. Health Place. 2008; 14(2):117-32..

2. Glanz K, Sallis JF, Saelens BE, Frank LD. Healthy nutrition environments: concepts and measures. Am J Health Promot. 2005;19(5):330-3.

3. Story M, Kaphingst KM, Robinson-O'Brien R, Glanz K. Creating healthy food and eating environments: policy and environmental approaches. Annu Rev Public Health. 2008;29:253-72.

4. Sallis JF, Owen N, Fisher EB. Ecological models of health behavior. Health behavior and health education: Theory, research, and practice. 4th ed. San Francisco: Jossey-Bass; 2008. p. 465-85.

5. Wendel-Vos W, Droomers M, Kremers S, Brug J, van Lenthe F. Potential environmental determinants of physical activity in adults: a systematic review. Obes Rev. 2007:8(5):425-40.

6. Van Cauwenberg J, Nathan A, Barnett A, Barnett DW, Cerin E. Relationships between neighbourhood physical environmental attributes and older adults' leisure-time physical activity: a systematic review and meta-analysis. Sports Med. 2018;48(7):1635-60.

7. Townshend T, Lake A. Obesogenic environments: current evidence of the built and food environments. Perspect Public Health. 2017;137(1):38-44.

8. Cerin E, Nathan A, van Cauwenberg J, Barnett DW, Barnett A. The neighbourhood physical environment and active travel in older adults: a systematic review and meta-analysis. Int J Behav Nutr Phys Act. 2017;14(1):15.

9. Bancroft C, Joshi S, Rundle A, Hutson M, Chong C, Weiss CC, et al. Association of proximity and density of parks and objectively measured physical activity in the United States: a systematic review. Soc Sci Med. 2015;138:22-30

10. Caspi CE, Sorensen G, Subramanian SV, Kawachi I. The local food environment and diet: a systematic review. Health Place. 2012;18(5): $1172-87$.

11. Brennan B, Sciandra M. Moving to opportunity (MTO) for fair housing demonstration program: history of MTO; 2000. http://www.nber.org/ mtopublic/ updated 2000.

12. Boone-Heinonen J, Gordon-Larsen P, Guilkey DK, Jacobs DR Jr, Popkin BM. Environment and physical activity dynamics: the role of residential selfselection. Psychol Sport Exerc. 2011;12(1):54-60.
13. McCormack GR, Shiell A. In search of causality: a systematic review of the relationship between the built environment and physical activity among adults. Int J Behav Nutr Phys Act. 2011;8:125.

14. Ouzzani M, Hammady H, Fedorowicz Z. Rayyan - a web and mobile app for systematic reviews. Syst Rev. 2016;5:210.

15. Alves L, Silva S, Severo M, Costa D, Pina MF, Barros H, et al. Association between neighborhood deprivation and fruits and vegetables consumption and leisure-time physical activity: a cross-sectional multilevel analysis. BMC Public Health. 2013;13:1103.

16. Boarnet MG, Joh K, Siembab W, Fulton W, Nguyen MT. Retrofitting the suburbs to increase walking: evidence from a land-use-travel study. Urban Stud. 2011:48(1):129-59.

17. Boone-Heinonen J, Gordon-Larsen P, Kiefe Cl, Shikany JM, Lewis CE, Popkin BM. Fast food restaurants and food stores - longitudinal associations with diet in young to middle-aged adults: the CARDIA study. Arch Intern Med. 2011;171(13):1162-70.

18. Boone-Heinonen J, Diez Roux AV, Kiefe Cl, Lewis CE, Guilkey DK, GordonLarsen P. Neighborhood socioeconomic status predictors of physical activity through young to middle adulthood: the CARDIA study. Soc Sci Med. 2011; 72(5):641-9.

19. Brown SC, Pantin H, Lombard J, Toro M, Huang S, Plater-Zyberk E, et al. Walk score(R): associations with purposive walking in recent Cuban immigrants. Am J Prev Med. 2013;45(2):202-6.

20. Brown SC, Lombard J, Toro M, Huang S, Perrino T, Perez-Gomez G, et al. Walking and proximity to the urban growth boundary and central business district. Am J Prev Med. 2014;47(4):481-6.

21. Cerin E, Frank LD, Sallis JF, Saelens BE, Conway TL, Chapman JE, et al. From neighborhood design and food options to residents' weight status. Appetite. 2011;56(3):693-703.

22. Christian H, Knuiman M, Bull F, Timperio A, Foster S, Divitini M, et al. A new urban planning code's impact on walking: the RESIDential environments project. Am J Public Health. 2013;103(7):1219-28.

23. Foster S, Hooper P, Knuiman M, Christian H, Bull F, Giles-Corti B. Safe Residential environments? A longitudinal analysis of the influence of crimerelated safety on walking. Int J Behav Nutr Phys Act. 2016;13:22.

24. Frank LD, Saelens BE, Powell KE, Chapman JE. Stepping towards causation: do built environments or neighborhood and travel preferences explain physical activity, driving, and obesity? Soc Sci Med. 2007:65(9):1898-914.

25. Frank LD, Kershaw SE, Chapman JE, Campbell M, Swinkels HM. The unmet demand for walkability: disparities between preferences and actual choices for residential environments in Toronto and Vancouver. Can J Public Health. 2014;106(1):eS12-21.

26. Giles-Corti B, Bull F, Knuiman M, McCormack G, Van Niel K, Timperio A, et al. The influence of urban design on neighbourhood walking following residential relocation: longitudinal results from the RESIDE study. Soc Sci Med. 2013;77(1):20-30.

27. Hajna S, Ross NA, Joseph L, Harper S, Dasgupta K. Neighbourhood walkability and daily steps in adults with type 2 diabetes. PLoS One. 2016; 11(3):e0151544.

28. Handy SL, Cao X, Mokhtarian PL. The causal influence of neighborhood design on physical activity within the neighborhood: evidence from northern California. Am J Health Promot. 2008;22(5):350-8.

29. Jack E, McCormack GR. The associations between objectively-determined and self-reported urban form characteristics and neighborhood-based walking in adults. Int J Behav Nutr Phys Act. 2014;11(1):71.

30. Kaczynski AT, Mowen AJ. Does self-selection influence the relationship between park availability and physical activity? Prev Med. 2011;52(1):23-5.

31. Knuiman MW, Christian HE, Divitini ML, Foster SA, Bull FC, Badland HM, et al. A longitudinal analysis of the influence of the neighborhood built environment on walking for transportation: the RESIDE study. Am J Epidemiol. 2014;180(5):453-61.

32. Lee JS, Zegras PC, Ben-Joseph E. Safely active mobility for urban baby boomers: the role of neighborhood design. Accid Anal Prev. 2013;61:153-66.

33. MacDonald JM, Stokes RJ, Cohen DA, Kofner A, Ridgeway GK. The effect of light rail transit on body mass index and physical activity. Am J Prev Med. 2010;39(2):105-12.

34. McCormack GR, Shiell A, Giles-Corti B, Begg S, Veerman JL, Geelhoed E, et al. The association between sidewalk length and walking for different purposes in established neighborhoods. Int J Behav Nutr Phys Act. 2012;9:92. 
35. McCormack GR, Friedenreich C, Salack BA, Giles-Corti B, Doyle-Baker PK, Shiell A. The relationship between cluster-analysis derived walkability and local recreational and transportation walking among Canadian adults. Health Place. 2012;18(5):1079-87.

36. McCormack GR, McLaren L, Salvo G, Blackstaffe A. Changes in objectivelydetermined walkability and physical activity in adults: a quasi-longitudinal residential relocation study. Int J Environ Res Public Health. 2017;14:5.

37. Nichani V, Dirks K, Burns B, Bird A, Morton S, Grant C. Green space and physical activity in pregnant women: evidence from the growing up in New Zealand study. J Phys Act Health. 2016;13(12):1341-50.

38. Norman GJ, Carlson JA, O'Mara S, Sallis JF, Patrick K, Frank LD, et al. Neighborhood preference, walkability and walking in overweight/obese men. Am J Health Behav. 2013;37(2):277-82.

39. Owen N, Cerin E, Leslie E, Coffee N, Frank LD, et al. Neighborhood walkability and the walking behavior of Australian adults. Am J Prev Med. 2007:33(5):387-95.

40. Saelens BE, Sallis JF, Frank LD, Cain KL, Conway TL, Chapman JE, et al. Neighborhood environment and psychosocial correlates of adults' physical activity. Med Sci Sports Exerc. 2012;44(4):637-46.

41. Sallis JF, Saelens BE, Frank LD, Conway TL, Slymen DJ, Cain KL, et al. Neighborhood built environment and income: examining multiple health outcomes. Soc Sci Med. 2009;68(7):1285-93.

42. Van Dyck D, Cardon G, Deforche B, Owen N, De Bourdeaudhuij I. Relationships between neighborhood walkability and adults' physical activity: how important is residential self-selection? Health Place. 2011;17(4): 1011-4.

43. Wells NM, Yang Y. Neighborhood design and walking. A quasi-experimental longitudinal study. Am J Prev Med. 2008;34(4):313-9.

44. West ST, Shores KA. Does building a greenway promote physical activity among proximate residents? J Phys Act Health. 2015;12(1):52-7.

45. Witten $\mathrm{K}$, Blakely $\mathrm{T}$, Bagheri N, Badland H, Ivory V, Pearce J, et al. Neighborhood built environment and transport and leisure physical activity: findings using objective exposure and outcome measures in New Zealand. Environ Health Perspect. 2012;120(7):971-7.

46. Frohlich KL, Mykhalovskiy E, Miller F, Daniel M. Advancing the population health agenda - encouraging the integration of social theory into population health research and practice. Can J Public Health. 2004;95(5): 392-5.

47. Kawachi IBL. Neighborhoods and health. New York: Oxford University Press; 2003.

48. Bandura A. Social foundations of thought and action: a social cognitive theory: prentice-hall; 1986.

49. Perlman D, Cozby PC, Issues SftPSoS. Social psychology: Holt, Rinehart, and Winston; 1983.

50. Williamson E, Morley R, Lucas A, Carpenter J. Propensity scores: from naive enthusiasm to intuitive understanding. Stat Methods Med Res. 2012;21(3): 273-93.

51. Gunasekara Fl, Richardson K, Carter K, Blakely T. Fixed effects analysis of repeated measures data. Int J Epidemiol. 2014;43(1):264-9.

52. Grafova IB, Freedman VA, Lurie N, Kumar R, Rogowski J. The difference-indifference method: assessing the selection bias in the effects of neighborhood environment on health. Econ Hum Biol. 2014;13:20-33.

53. Arcaya M, Tucker-Seeley R, Kim R, Schnake-Mahl A, So M, Subramanian SV. Research on neighborhood effects on health in the United States: a systematic review of study characteristics. Soc Sci Med. 2016;168:16-29.

54. Mayne SL, Auchincloss AH, Michael YL. Impact of policy and built environment changes on obesity-related outcomes: a systematic review of naturally occurring experiments. Obes Rev. 2015;16(5):362-75.

55. Petticrew M, Cummins S, Ferrell C, Findlay A, Higgins C, Hoy C, et al. Natural experiments: an underused tool for public health? Public Health. 2005; 119(9):751-7.

56. Heinen E, Mackett R, van Wee B, Ogilvie D, Panter J. Residential selfselection in quasi-experimental and natural experimental studies. J Transport Land Use. 2018;11(1):939-59.

57. Oakes JM. Commentary: advancing neighbourhood-effects researchselection, inferential support, and structural confounding. Int J Epidemiol. 2006;35(3):643-7.

58. Bilger $M$, Carrieri V. Health in the cities: when the neighborhood matters more than income. J Health Econ. 2013;32(1):1-11.

59. Zick CD, Hanson H, Fan JX, Smith KR, Kowaleski-Jones L, Brown BB, et al. Revisiting the relationship between neighbourhood environment and BMI: an instrumental variables approach to correcting for residential selection bias. Int J Behav Nutr Phys Act. 2013;10:27.

\section{Publisher's Note}

Springer Nature remains neutral with regard to jurisdictional claims in published maps and institutional affiliations.

\section{Ready to submit your research? Choose BMC and benefit from:}

- fast, convenient online submission

- thorough peer review by experienced researchers in your field

- rapid publication on acceptance

- support for research data, including large and complex data types

- gold Open Access which fosters wider collaboration and increased citations

- maximum visibility for your research: over $100 \mathrm{M}$ website views per year

At $\mathrm{BMC}$, research is always in progress.

Learn more biomedcentral.com/submissions 